\title{
CAMILO, Vagner. Drummond: da Rosa do povo à Rosa das trevas. São Paulo: Ateliê Editorial, 2001.
}

Sérgio Alves Peixoto Universidade Federal de Minas Gerais

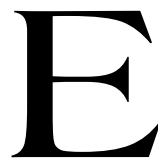

screver sobre um poeta como Carlos Drummond de Andrade, cuja fortuna crítica é bastante extensa e de grande qualidade, não deixa de ser um empreendimento perigoso. Pode-se cair na mesmice, repetindo-se o que já foi dito, ou acabar dizendo o que não tem grande relevância. Esse não é bem o caso do livro de Vagner Camilo: sem deixar de concordar em muitos aspectos com o que se tem falado sobre a poesia de Drummond, seu autor acrescenta à obra do poeta mineiro uma leitura própria e, no mínimo, instigante.

O objetivo principal de Vagner Camilo é mostrar como o projeto lírico de Drummond sofre grande modificação no ano de 1951, quando ele publica Claro enigma, seu mais desconcertante livro de poemas. Mas o crítico não fica só nisso: busca apontar as razões dessa modificação, relacionando o novo projeto estético do poeta itabirano a uma decepção com o mundo que o circundava, a um pessimismo que tinha tudo a ver com o panorama do pós-guerra e, mais especificamente, ao desencanto com o dogmatismo e o populismo que o realismo socialista queria impor.

Assim, vemos como Drummond, que tinha assumido claramente uma participação social e política, principalmente com o conhecidíssimo A rosa do povo, de 1945, passa a dizer, no livro de 1951, que "os acontecimentos o aborrecem." Estamos falando aqui da epígrafe escolhida para Claro enigma, um famoso verso de Paul Valéry, verso esse que deixou ainda mais enraivecida uma certa crítica que cobrava o engajamento do 
artista. Camilo chega a afirmar, através de citação de José Guilherme Merquior, que, ao escolher o verso do poeta francês, Drummond "estava perfeitamente consciente do desafio que lançava ao moralismo simplista da maior parte do intelectualismo engajado" (p.44).

$\mathrm{Na}$ verdade, o estudo de Vagner Camilo acaba centrando-se mais na releitura de Claro enigma, fruto de um poeta que não mais acreditava nos ideais revolucionários do socialismo a que tinha se filiado, que se tinha desiludido com o fanatismo de seus amigos do Partido Comunista Brasileiro, que se tinha tornado um pessimista, mas nunca um alienado. Ao voltarse para uma poesia vazada principalmente na forma do soneto, muitas vezes visto pejorativamente como herança parnasiana, Vagner Camilo mostra que Drummond, na verdade, desestruturou-o com uma constante ironia que punha por terra não só a própria forma escolhida, mas também a serena e impoluta linguagem dos mais requintados mestres do Parnaso. Um dos sonetos escolhidos por Camilo para rebater a crítica que tinha visto Claro enigma como um livro retrógrado e "parnasiano" é o famoso "Oficina irritada" que, já pelo título, põe abaixo a impassibilidade do parnasianismo.

Para desenvolver sua releitura de Claro enigma, Vagner
Camilo parte exatamente de uma outra: a da fortuna crítica sobre essa "guinada classicizante" do poeta mineiro. Aí, ele aponta erros fulcrais, principalmente no que diz respeito à aproximação do poeta com os da chamada Geração de 45, estes, sim, voltados para um formalismo estetizante e vazio. Camilo mostra, então, como isso é falso em Drummond, poeta para quem a noção de torre-de-marfim não tem nada a ver com alienação. Pelo contrário, o isolamento do poeta, essa sua retirada estratégica para uma espécie nova de torre-demarfim, é o que exatamente lhe permitiu, mais nitidamente, ver e ver-se, criticar e criticar-se. É em Claro enigma que Drummond deixa transparecer melhor sua visão paradoxal do mundo, da poesia e de si mesmo. E é em sua torre que o poeta analisa o impasse em que vivia, isto é: participar do mundo, sem ser dogmático, como muitos exigiam que ele fosse, e exercer seu trabalho de poeta, sem cair no esteticismo alienante em que muitos poetas seus contemporâneos acabaram caindo.

Gostaríamos, agora, de apontar dois problemas na obra de Vagner Camilo. O primeiro são os extensos comentários sobre os contextos histórico e político, que acabam sendo um ponto de desequilíbrio no livro, não porque estejam aí deslocados, mas porque 
são excessivos. Nesse momento, o crítico deixa de lado a poesia, voltando-se, insistente e repetitivamente, para a história e a política, como se sentisse necessidade de estar sempre se respaldando em elementos extra-literários para embasar a análise da poesia de Drummond. Isso, quando bem dosado, tem sua função e eficácia. Mas no caso do presente livro é um defeito, embora pequeno. A obra perde seu ritmo, e a leitura fica cansativa. Acreditamos que tal fato se deva ao livro de Vagner Camilo ser fruto de uma tese de doutorado, tipo de texto acadêmico em que se tem de estar, a todo momento, mostrando à banca examinadora que se teve um grande trabalho e uma grande leitura teórica. As modificações que o texto sofreu, ao se transformar em livro, não conseguiram eliminar o que vemos como uma falha na obra, tornando sua leitura muitas vezes cansativa e desinteressante.

Um outro pequeno problema aparece quando a análise de textos passa a ser especificamente o centro da atenção de Vagner Camilo. Ao estudar determinados poemas, ele, ao contrário do que esperávamos, se torna apressado, sem querermos dizer superficial. Muitas de suas análises poderiam ter sido mais aprofundadas e algumas paráfrases evitadas. Afinal de contas, é da poesia de Drummond que o crítico pretende falar.

O que acabamos de dizer não desmerece em nada o livro de Vagner Camilo, como um todo. Seu conhecimento de poesia em geral e principalmente da poesia de Drummond é consistente. Disso ele nos dá provas, quando retoma, em comparações que faz durante seu trabalho, a poesia de Mário de Andrade e de outros poetas do Modernismo brasileiro para melhor avaliar tanto as "inquietudes" de Drummond, como disse Antonio Cândido, quanto a posição do itabirano como homem e poeta de seu tempo.

Dentro de uma obra instigante como a de Vagner Camilo, gostaríamos de ressaltar dois momentos. O primeiro, quando ele se debruça sobre um livro geralmente esquecido pela crítica: Novos poemas, publicado em 1948. Na análise que faz deste livro, Camilo mostra que aí já aparecem indícios da grande e inesperada mudança que viria a ser Claro enigma, três anos depois. Embora alguns textos ainda apresentem o cunho nitidamente participante encontrado nos publicados em A rosa do povo ("Notícias de Espanha", por exemplo), já se vêem outros de cunho metafísico e hermético, como é o caso do belíssimo soneto 
"Jardim", espécie de precursor dos obscuros poemas de Claro Enigma, livro que representa essa espécie de poesia pura tão cara a Valéry.

O segundo momento é a parte mais extensa do livro, aquela em que o autor se detém mais especificamente em desvelar o claro enigma de Drummond. Aqui, uma novidade: o crítico não vai buscar, como seria de esperar, o sempre lembrado e cultuado poema "A máquina do mundo", mas um outro, o quase esquecido "Relógio do Rosário". É neste poema que o enigma drummondiano, segundo Camilo, se deixa ver claramente, pois nele o poeta tematiza o homem e sua dor de existir. Com este poema, a culpa por não ter conseguido resolver os problemas da humanidade de que tanto falou em livros anteriores dá uma dimensão trágica ao poeta e a sua obra, colocando Claro enigma como um dos grandes momentos da trajetória poética de Drummond. Não poderíamos terminar sem dizer que o estudo de Vagner Camilo é consistente, de grande fôlego e muito bem arquitetado. Nele se discutem temas complexos sobre a poesia de Drummond que o espaço de uma resenha não consegue dar conta. Vale a pena ler o trabalho de Camilo, como vale a pena sempre voltar a Drummond e a seu claro enigma. 